\title{
Urban Activist
}

\section{CHRISTOPHER MEYER}

University of Miami

THE MISSISSIPPI RIVER DELTA AS HUMAN CONSTRUCT History provides accounts of the settlements in the Mississippi River delta flourishing in the river's rich alluvial soils; suggesting the amount of riches one could amass is limited only upon the capacity of one to clear existing vegetation from the landscape-cultivating natural ecologies to agriculture. Coupled to the development of these agricultural settings are littoral urbanisms; these urban fabrics range from rural clusters of individual habitats to complex urbanisms fostering networks of industry, trade, and transportation. As the newly established agricultures and urbanisms matured in place; these human controlled environments began to show signs of opposition to the very delta environment that conceived them. Natural river patterns of movement, bending, meandering, sediment, erosion, contraction and expansion became antagonists to the static agricultural and urban environments. These natural dynamisms were given equally antagonistic, often hostile, references as : flooding, drowning, engulfing, submerging. A subtle, but perceptible, change of dialect allows a natural river action to transform into an action of intent acting upon something else. The river is not merely expanding and contracting, but flooding the surrounding settlements. As if an intention exists to disrupt and disorder humankind's control of environment. This shift in language is a first step into the Anthropocene; the establishment of nature as subservient to humankind. A false transposing of man's control over environment.

It was determined the continued existence [and prospering] of these established agricultural and urban networks within the Mississippi River delta are dependant upon the ability to control the pattern of floodwaters from the Mississippi River, establishing a mindset of nature as antagonist and setting forth centuries of opposition between constructed and natural environments.

Intially strategies of environmental management along the river were limited to small scale interventions and assembled in a piecemeal manner, this collection of interventions lacked cohesion limiting its capacity to behave as a comprehensive infrastructure of management. Under the Military Commission and then the Army Corp. of Engineers the environmental control structures were linked, creating an extensive network of environmental control structures spanning thousands of miles. The expanding environmental control infrastructure altered the river system from a dynamic existence defined by the natural oscillation of the river bed and its associated shoreline into a static condition

\section{SHAWNA MEYER}

University of Miami

constricting the river's natural migratory pattern. The fixed edge, constructed by mankind to mediate between the natural environment the constructed environment, transformed a language of ebbing, flowing, meandering, eroding, and depositing to a vocabulary of levee, spillway, dikes, inlets, outlets, pump stations, canals and cuts. Settlements within the delta territory became increasingly dependent upon the ability of the constructed edge to prevent environmental fluctuations. Urban development set in motion environmental management as necessity and entitlement to human inhabitants for protection from environmental damage. Coupled with the physical network of control infrastructures, an intricate network of commissions and policies were established throughout the delta territory ${ }^{1}$. Mission statements defined by levee boards and commissions reinforced the need to dictate environmental settings:

The mission of the Board of Levee Commissioners for the Yazoo-Mississippi Delta is to erect and maintain a system of levees to protect the people and property of the Delta from damages from high waters of the Mississippi River. It also directs the necessary activities to protect lives and property from the threat of flooding from interior streams, and furnishes the local cooperation for various flood control projects of the U.S. Army Corps of Engineers. ${ }^{2}$

-Yazoo-Mississippi Delta Levee District, Mission Statement

The ability for a long term existence of the urbanisms rooted in the shadows of control infrastructure networks hinge on their ability to dictate natural patterns. The sediment, or progradation, is a natural pattern of the mouth of a river system to move slowly back and forth across the delta, a larger scale territorial migration pattern. The river's movement across the delta deposits sediments evenly building up the shoreline and supporting a robust ecological network of flora that stabilized the soil. These natural ecologies are a complex ecosystem of plants, animals, soils, and water that existed in a fluid and dynamic, yet stable river environment fostering the formation of the river delta and buffering erosion.

\section{THE LOST CONTROL OF THE CONTROL SYSTEM}

As the Mississippi River flows south towards the Gulf of Mexico just north of Baton Rouge the Old River Control Structure constructed by the Army Corp. of Engineers in $1963^{3}$ bifurcates 
the river system into the Atchafalaya River and Mississippi River respectfully. The control structure was built over three decades, delayed by intermittent floodings and subsequent control failures setting back the schedule. Old River Control Structure was conceived by the Army Corp of Engineers to regulate the amount of water each river system will receive, both as a means to manage fluctuations in river stages during flood events but more importantly to prevent the Mississippi River from evolving into an affluent of the Atchafalaya River. Highly regarded as a testament to engineering achievement of environmental management, the Old River Control Structure stands as a mechanism controlling the river system in a static and bound state. In 1973, only 10 years after the completion of the O.R.C., flood waters would permanently damage the structure compromising its ability to regulate the water levels of the Mississippi River at full capacity, and foreshadowing its inevitable failure. Without the Old River Control Structure and associated spillways and levee network, the river would be free to roam across the state of Louisiana as depicted in the Radical Cartography by Harold Fisk. ${ }^{4}$

The work of Harold Fisk from 1944 collapses time and space to shift the perception of the Mississippi River's being, exposing the rivers propensity to move and flex as a living organism [FIG 1]. Viewing the landscape from Fisk's perspective challenges historical and conventional understandings of urban development strategies, traditionally conceived of as static and dependent on slow or the absence of change to surrounding environmental circumstances. The work of Fisk sets forth the fundamental premise of inhabiting the territory adjacent to the Mississippi River [and within the territory of the Mississippi Delta] which mankind and mankind's built environment must respect the systems need for constant change. Inhabiting the territory in any other method is to be both reckless and irresponsible for the balance of the environmental and ecological systems and for mankind's long term sustained existence in the territory. Reflecting on the words of Anthropologist Gregory Bateson, "The organism which destroys its environment, destroys itself."

Despite Fisk's work, the Mississippi and Atchafalaya Delta territories were developed as a rigid system comprised of a network of urban settlements whose survival is dependent upon the capacity of control infrastructures to restrict and restrain environmental fluctuations. A ramification related to control infrastructures is the limited progradation of the delta, making Louisiana's southern coast vulnerable to large scale erosion patterns. The sediment deposits in the pre-cultural period would be evenly distributed across the delta, however, the earthen levees funnel the majority of the sediment to the Gulf of Mexico producing sediment fans at the outlets. A consortium of forceserosion, saltwater intrusion, strom severity and frequency, thermal expansion of hydrological systems and sea level rise-are swiftly acting to alter the makeup of the delta and subsequently pressuring the stability of urbanism within the delta requiring new methods of existence and techniques of construction.

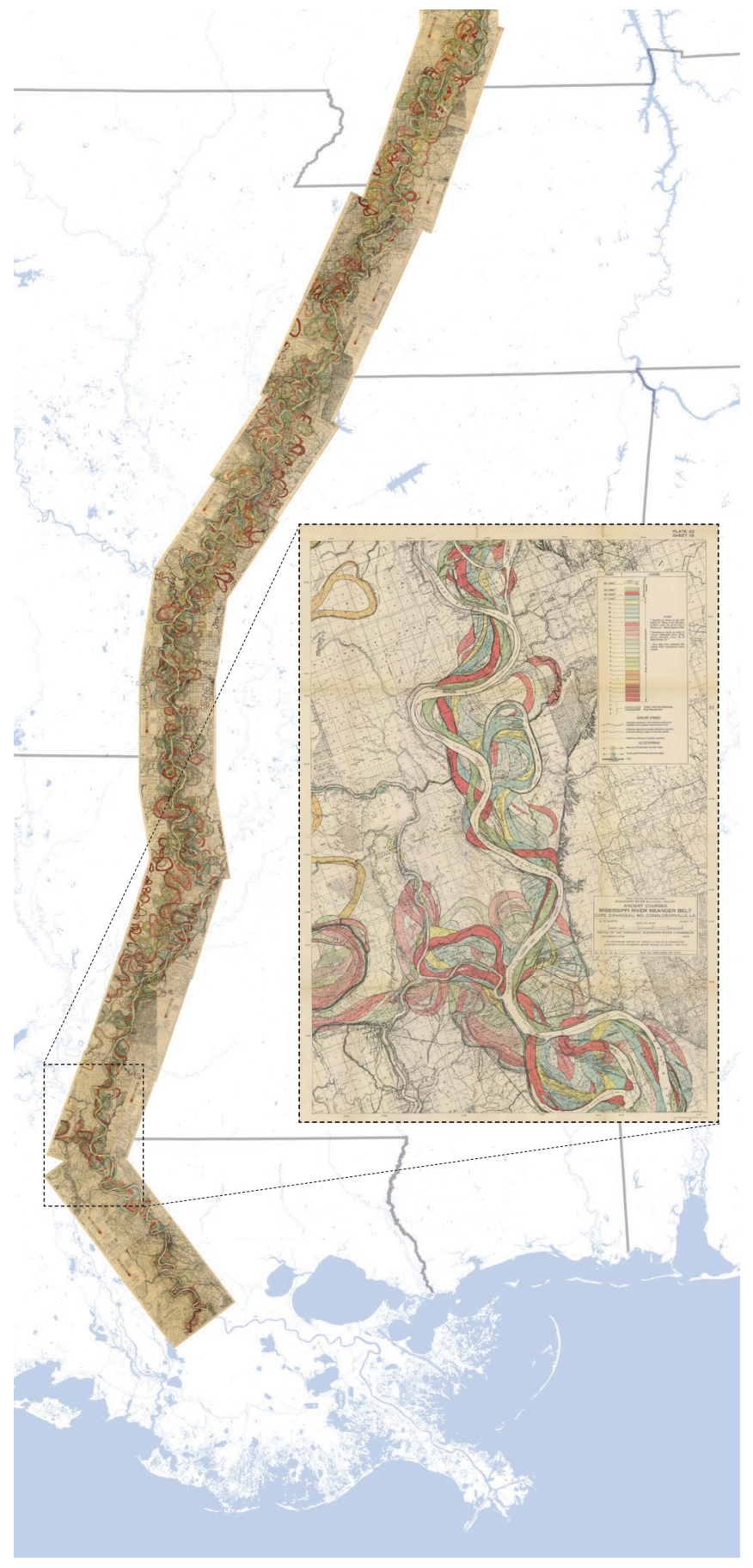

Figure 1. Collage of The Alluvial Valley of the Lower Mississippi River Radical Cartography, Harold Fisk, 1944.

\section{MORGAN CITY AS ENVIRONMENTAL ACTIVIST}

With claim to be located "right in the middle of everywhere" 5 the city of Morgan City exists within the Mississippi River and Atchafalaya River delta as the nexus of New Orleans, Baton Rouge, Lafayette and the Gulf of Mexico. A delta settlement dating to the 1700 s [initially occupied, but not 'settled' by the Attakapas Tribe] Morgan City is an example of urban development within the delta as described above. Existing first as a 
sugar cane plantation, a manipulation of the natural ecology to produce agriculture, and sited on the premise of the environmental value of place, Morgan City is tangibly tied to the delta's water network.[FIG 2] The Atchafalaya River defines the western edge of the city, while Lake Palourde defines the eastern edge and Flat Lake borders the city to the north. This dialogue between city and place was constructed as a lifeline and evolved to one of threat, now finds the static urbanism at increasing opposition with the dynamic delta territory. Morgan City, as a precedent settlement within the delta, must respond to increased weather events and atmospheric fluctuations [climate change] that signify a catastrophic future. Morgan City is a community completely dependant on the performance of environmental control.

As the Industrial Age pushed humankind's capacity to createcities grew, abilities expanded exponentially, and production of 'goods' was at high demand, Morgan City was established as a competing port city to New Orleans. The increase of density in the settlement is linked to evolving urban programs: agriculture, trade, transportation and industry in the form of jumbo shrimp and petroleum. In the mid 20th century, Morgan City was established as the global capital of offshore drilling. All these confluences work to support the need for Morgan City as an active urban participant, which contextually meant enclosing the city in a protective wrapper. Multiple storied concrete walls with rolling steel flood gates [FIG 3] negotiate the Atchafalaya River bank and the Morgan City's edge working to further constrict and control the river's flow. Additionally, a network of pump stations, overflow lagoons, and cuts into the existing urban fabric work congruently to restrain water pressures from Lake Palourde and Flat Lake [FIG 4]. In defiance of the constructed control infrastructures, the territory and the city continue to flood and increasing volumes of flood risk demand continued contribution of resource.

Historically, significant flood events-1916, 1922, 1927*, 1937 and $1973^{6}$ - tested to and past the breaking point of contemporary control infrastructures ability to limit environmental fluctuations. With each failure the systems would be rebuilt and reconfigured to be stronger, more robust, expanding their impact and search for rigidity. Continued investment in environmental control systems solidified delta urbanism dependance existence on their capacity to perform-failure of the infrastructure to perform resulted in devastation to the constructed environment. There is an immediate and reflexive nature of humans to begin the reconstruction process: stronger, protective, resilient, permanent, engineered, managed, controlled. This is the moment where the dialogue needs to change. We must begin to question why is this our approach to inhabiting these contexts? How did we establish this trajectory? It is time to re-frame the relationship between the built environment and ecology from one of antagonistic and control to one of coexistence. Reaching again outside of the immediate discipline of architecture, Bruno Latour attempts to frame the challenge for humankind to un-control nature:

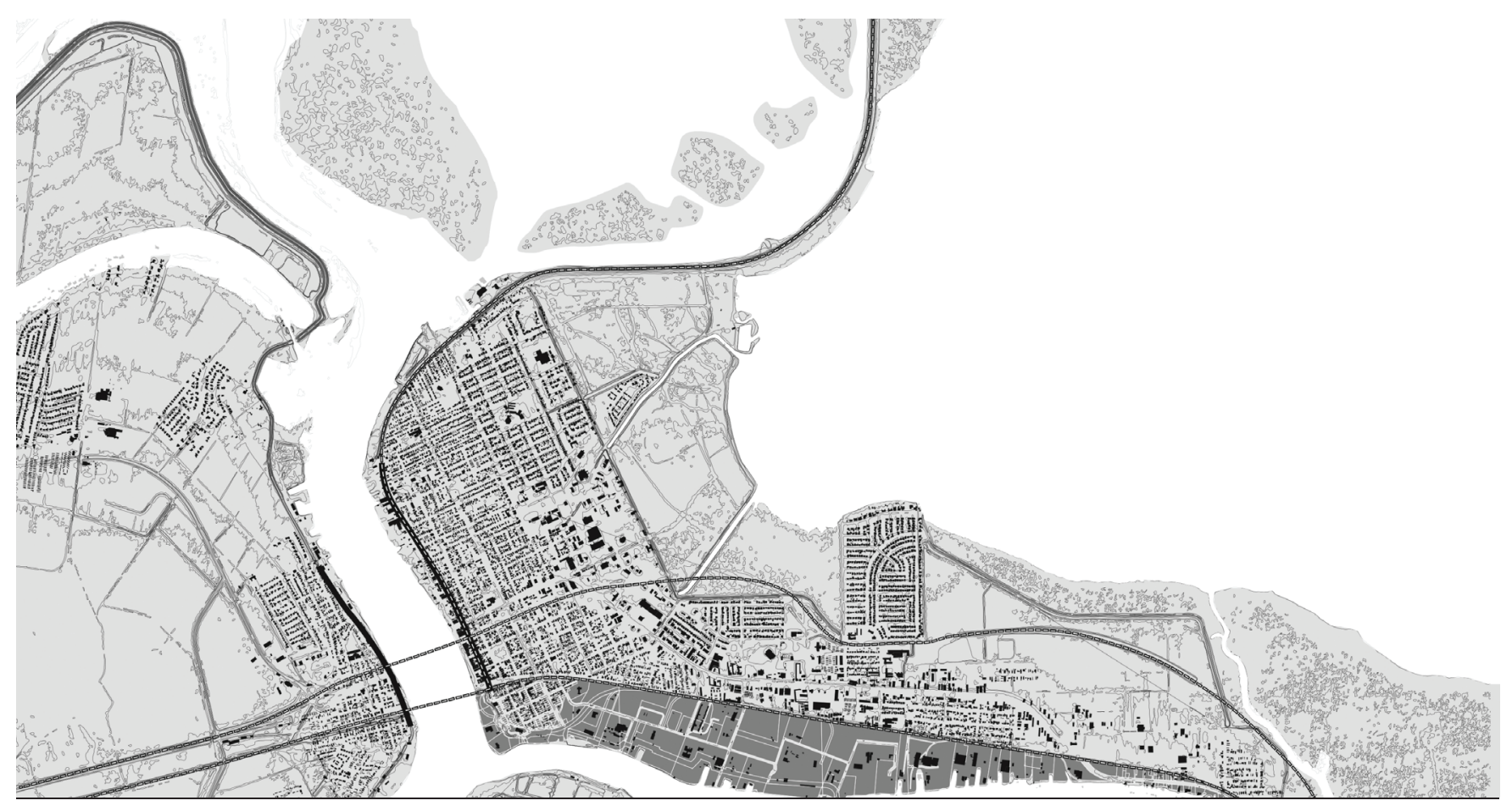

Figure 2. Excerpt from Buoyant Clarity, Pamphlet Architecture $36 .{ }^{8}$ 


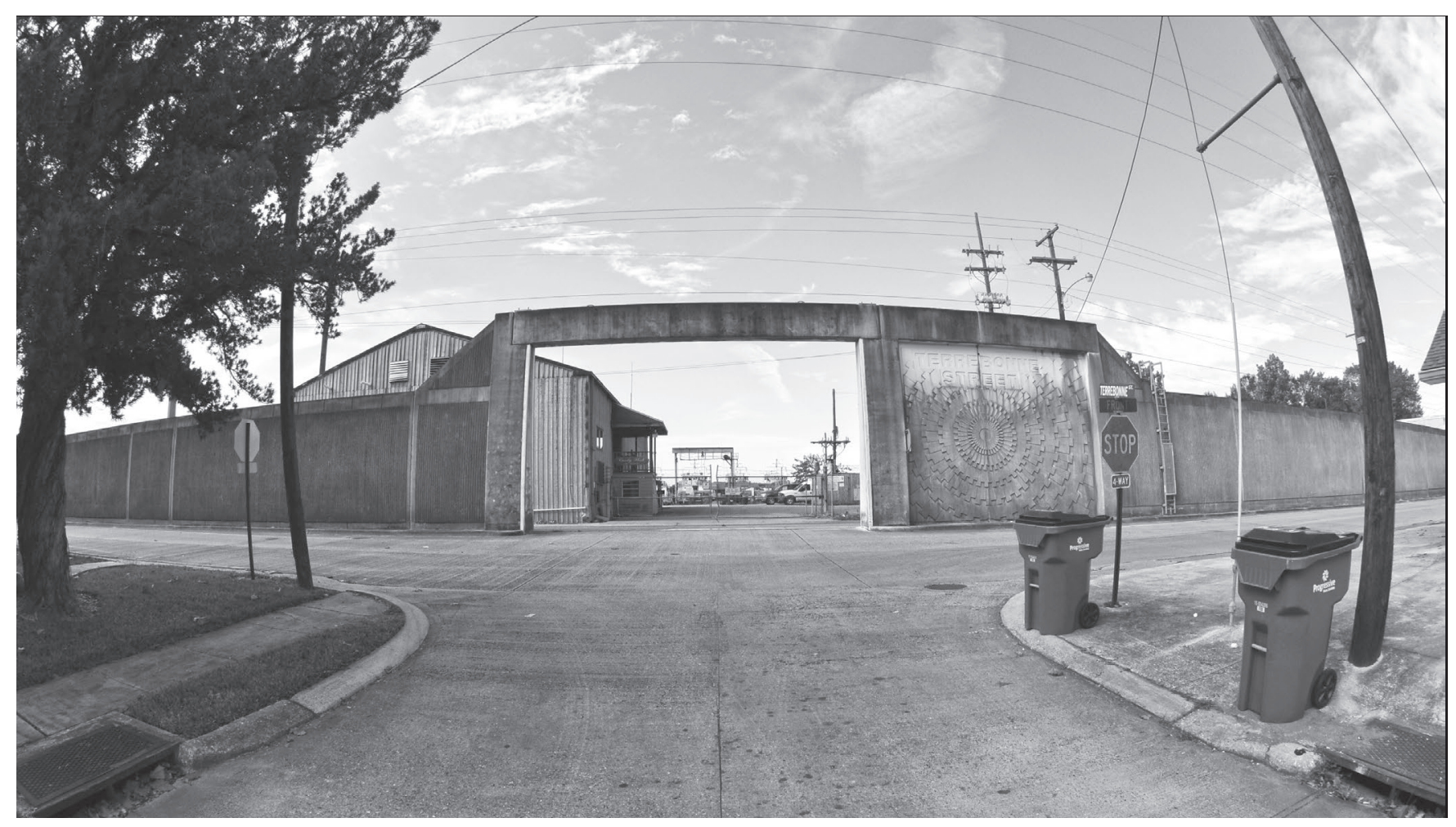

Figure 3. Imagery from Buoyant Clarity, Pamphlet Architecture $36 .^{8}$

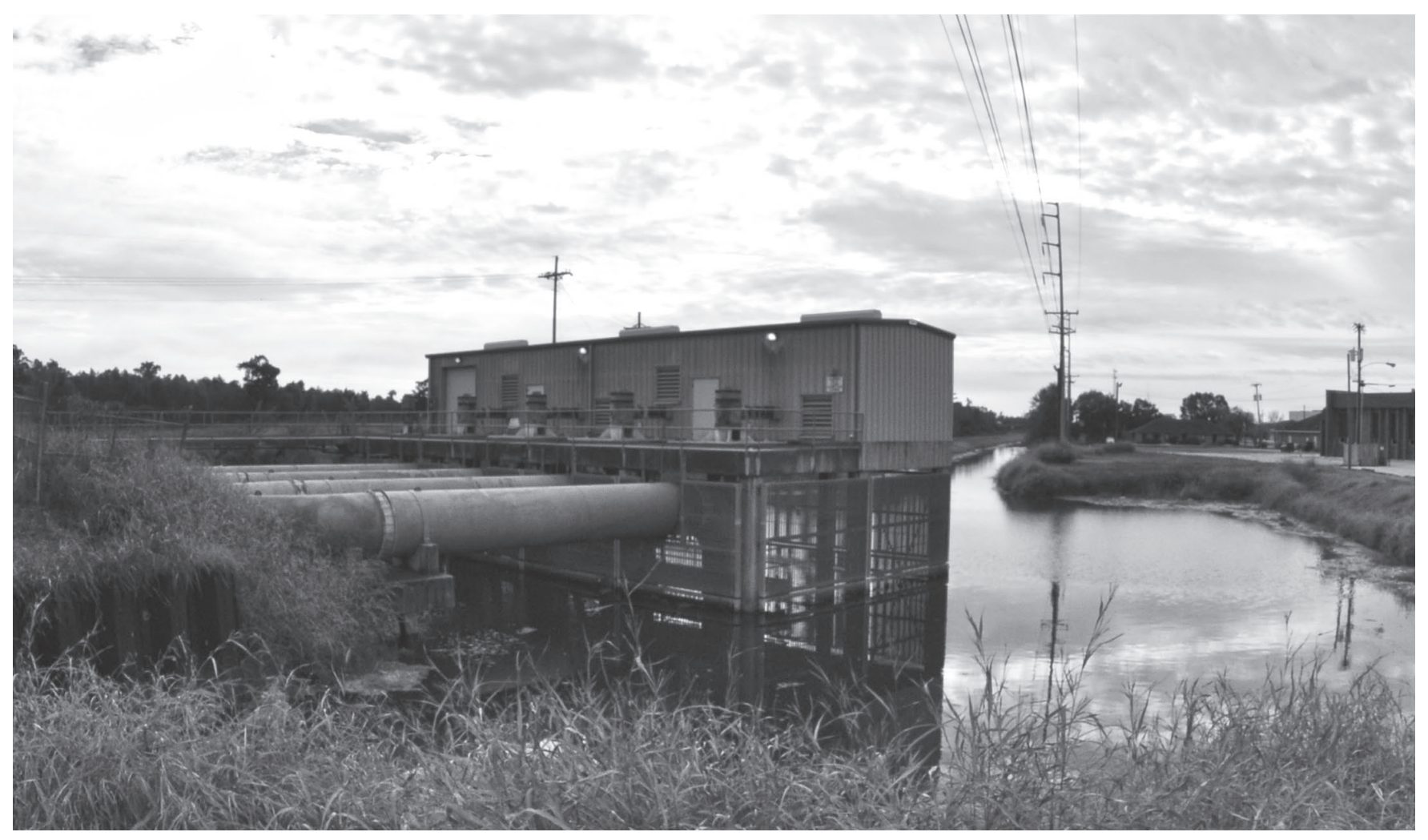


Today, this bifurcated nature partly explains a sort of indifference or scepticism in regard to Gaia. It is as if nature were acting out of character, no longer that which human rationality conquers, but that which plunges us into disarray; it is not longer the backdrop for our human projects, with no project of its own, but is intruding in our dreams, values and projects. How can one not give in to the double temptation of either climatic scepticism, or geoengineering that would put nature back in its place as the thing we should be able to dominate? ${ }^{7}$

Latour's statement calls for a reflection on the established relationship between humankind's built environment, control infrastructures, and ecological systems within the delta territory; a questioning of the antiquated anthropocentric roles of their relationship. Environment's capacity to 'act out of character' is a human construct, instilling nature with a being, often defined as menacing and problematic, which reinforces the human agenda to maintain a blind trajectory towards control. It is within this circumstance exists the most anthropocentric act- human's capacity to choose. The Urban Activist proposes an urban agenda committed to the recovery of ecological authority. To maintain the current existence of environmental management is to continue a commitment to the allocation of resources for control infrastructures; ergo a commitment to the redevelopment of control infrastructures after inevitable failure. In contrast, to accept an inevitable failure of control infrastructure is to accept disruption. To choose disruption, is to acknowledge the unplanned, the unphotogenic, the disorder and the disarray.

Exploring the depiction of the disruptor through an urban and architectural lens one envisions the city in a fluid and dynamic condition; water ebbs in and out of the urban fabrics and city boundaries and hard edges are absolved and blurred. A renewed ecology blends constructed environments with natural environments-architecture accepts place and ecological authority is recovered. This projected future is forged through choice: the planned deconstruction of the urban fabric. In this scenario, Morgan City is an urban activist, the city sacrifices the urban status quo of static and controlled environments through a planned reconfiguring of the urban fabric. (FIG 5). The Process, as illustrated in figure 5, aims for the continued inhabitation of the delta territory; but with a renewed agenda and relative expectations. The following four phases describe a process of desettlement, reconfiguration, and shifting expectations of permanence within the delta urban fabrics.

\section{PHASE I: POST-INDUSTRIAL REVOLUTION DESETTLEMENT}

Increased investment in flood-control mechanisms and environmental-management strategies have defined the philosophy of delta settlement since the early nineteenth century. However, a juxtaposing framework of rising water and ecological crisis suggests a divestment in man-made protection interventions, and even the decommissioning of the city. This map sets forth the first step toward the recomposition of Morgan City to allow water to flow where buildings once stood. The low-lying regions of Morgan City are decommissioned first. It is critical to understand that decommissioning will require construction. As portions of Morgan City are dismantled, the reconfiguration of residences, commercial interests, institutions, and governmental facilities to sit on a compact footprint will require short-term architectural solutions that also coordinate timeline, capital investments, and embodied energy.

In Phase I, control systems are dismantled and a fluid transitional zone, defined by fluctuating water levels and changing pockets of terra firma, is allowed to take shape. Programmatically, the city's permanent and private settlement zones will be transformed into fluid, transitional public spaces, adaptable to evolving forms of recreational activity within the delta. Resources are allowed to flourish within this zone, suggesting a "new natural" within the anthropocentric ecology.

\section{PHASE II: DISMANTLING MANAGEMENT}

As the footprint of the urban fabric contracts, traces of the city's origins begin to surface. The strategies of decommissioning are committed to active participation in the networks of resource extraction, manipulation, and distribution that are vital to Morgan City, particularly the petroleum and shrimping industries. Commercial, institutional, governmental, and residential interests will migrate toward the western and northern edges of the industrial region.

Phase II proposes the continued dismantling of the various control mechanisms within and around Morgan City, allowing low-lying areas to absorb sea-level rise at a slow and steady pace. Simultaneously, the constructed levees to the west of the city continue to guide the Atchafalaya River south to the Gulf of Mexico, providing a buffer for the inhabited areas on higher ground at moments when the Atchafalaya River swells.

\section{PHASE III: CONTRACTED LIVING}

The final throes of Morgan City's desettlement: flood-control mechanisms, intermodal systems, networks of levees, sea walls, Louisiana Highway 182, US Route 90, and the BNSF and Union Pacific railways are decommissioned. The remaining portion of Morgan City becomes the southernmost section of Saint Mary Parish, accessible by Louisiana Highway 70 from the north. The decommissioning of Morgan City ultimately uncovers the difficult conversation that the delta and coastal communities will need to begin in the coming years: as the material city leaves, so too does its culture of place. The 


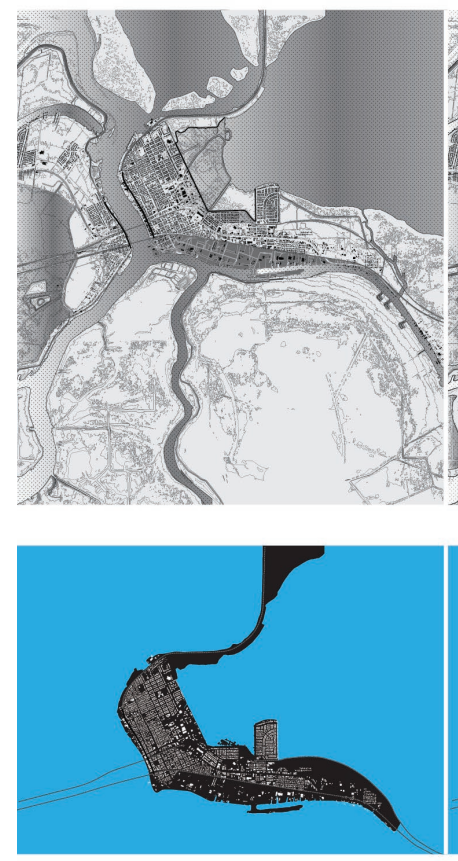

Phase I
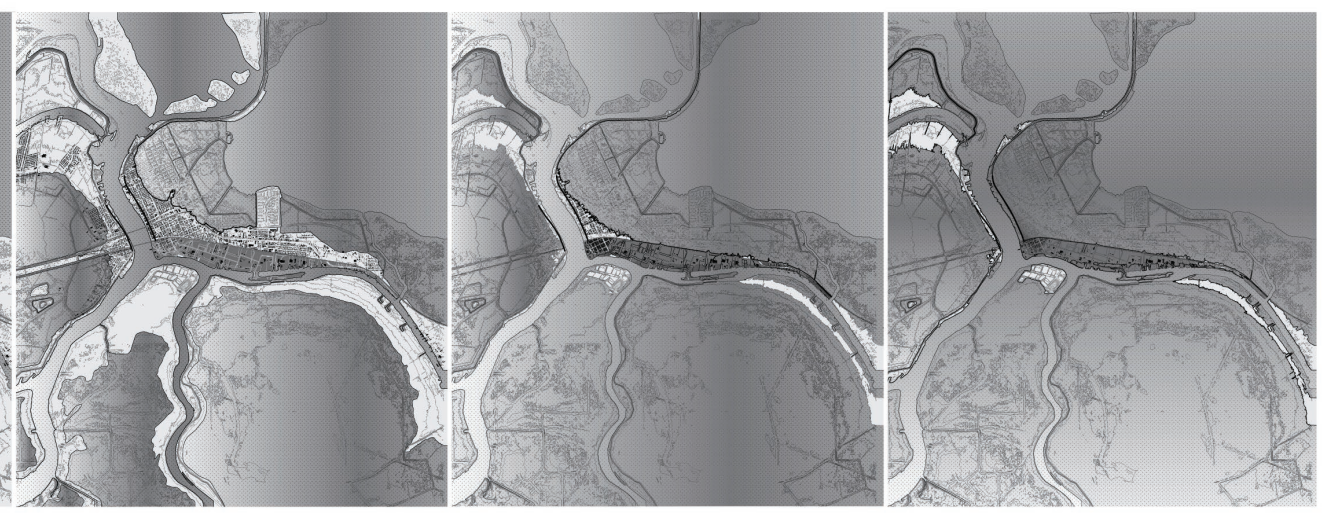

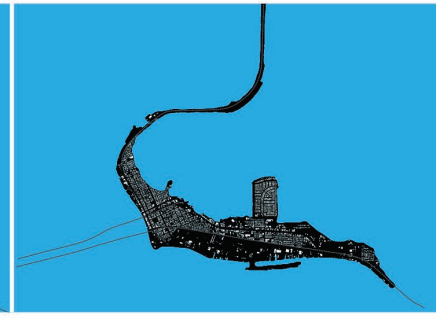

Phase II

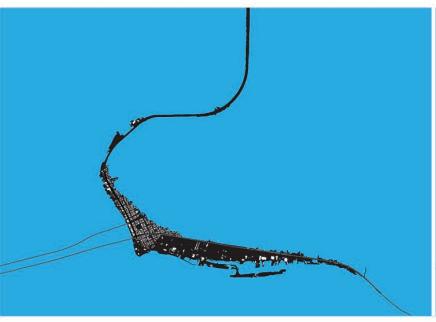

Phase III

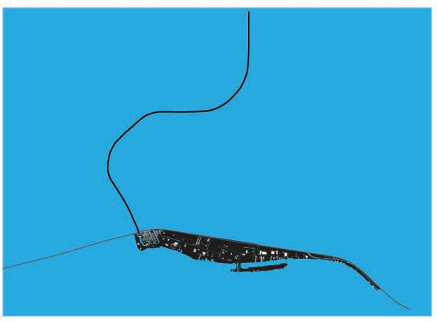

Phase IV

Figure 5. Excerpt from Buoyant Clarity, Pamphlet Architeture $36 .^{8}$

strategy to consciously decommission situates humankind as an active participant in the abandonment of human settlements in the delta. Can humankind learn to let go?

Phase III provides a framework for breaking habits. Morgan City is now almost unrecognizable in form and function from the twenty-first century methods of permanence in place, static habitats, and transportation infrastructure. In this future, transportation networks exist solely as aquatic movement patterns, and occupation of the city is temporal-focused on the needs of resource and industry supported by flexible and kinetic "residence hubs."

\section{PHASE IV: PORT DOCKING}

Sea-level rise, increased storm severity and frequency, and evolving delta flow patterns intensify habitation within the delta region. Traces of settlements mark a now distant postIndustrial Revolution era. The idea of control has eroded; in its place, an integrated dialogue of humankind and nature is found. The delta is littered with the markings of obsolete levee walls, now transformed into docking stations and cultural markers.

Phase IV suggests a concept of place found through a kinetic existence-one that acknowledges change and supports a focused experience of site. Industry remains; permanent settlements are gone. Infrastructures are decommissioned or adapted to an aquatic environment. Leisure also remains, building on historical traditions of interaction with the delta's flora and fauna.

\section{ENDNOTES}

11917 Flood Control, Appendix D, by the Sixty-Fourth Congress, Sess. II. Ch. 144. 1917

21928 Flood Control, Appendix E, by the Seventieth Congress, Sess. I. Ch. 596. 1928

3 “Our Mission Statement," Yazoo-Mississippi Delta Levee District official website. www.leveeboard.org/mission.html.

4 "Old River Control," New Orleans District, U.S. Army Corps of Engineers official website. www.mvn.usace.army.mil/Missions/Recreation/Old-River-Control/.

5 Harold Fisk, The Alluvial Valley of the Lower Mississippi River, map, 1944, Radical Cartography website. http://www.radicalcartography.net/index.html?fisk.

6 "History of Morgan City, La.," Morgan City official website. www.cityofmc.com/ index.php/aboutmorgan-city/morgan-city-history.html.

7 “Mississippi River Flood History 1543-Present," National Weather Service/ NOAA official website, accessed May 21, 2018. www.weather.gov/lix/ ms_flood_history.

8 Bruno Latour and Christophe Leclercq, eds., Reset Modernity! (Karlsruhe: ZKM, Center for Art and Media, 2016).

9 Christopher Michael Meyer et al., Pamphlet Architecture 36: Buoyant Clarity (New York: Princeton Architectural Press, 2018). 